\title{
КАЗАХСТАНСКИЙ АРХЕОЛОГ УДОСТОЕН ЯПОНСКОЙ НАГРАДЫ «ОРДЕН ВОСХОДЯЩЕГО СОЛНЦА С ЗОЛОТЫМИ ЛУЧАМИ, С ЛЕНТОЙ НА ШЕЕ»
}

\author{
(C) 2020 г. Т. Б. Мамиров
}

В статье приводятся некоторые итоги научной деятельности известного археолога Жакена Кожахметовича Таймагамбетова. Основное внимание уделено становлению Ж. К. Таймагамбетова как ученого, сотрудничеству с японскими археологами, и научном вкладе исследователя в изучение палеолита Казахстана. Научные интересы ученого: антропогенез, история древнейших культур Евразии, проблемы заселения территории Центральной Азии и Казахстана первобытным человеком.

Ключевые слова: археология, Ж. К. Таймагамбетов, наука, ученый, каменный век, палеолит

3 ноября 2019 г. Правительство Японии опубликовало список иностранных граждан, которые будут награждены от имени Императора Японии Нарухито «Орденом Восходящего солнца с золотыми лучами, с лентой на шее». Среди кавалеров ордена отмечен наш соотечественник, один из ведущих археологов страны, членкорреспондент НАН РК, доктор исторических наук, профессор, главный научный сотрудник Национального музея Республики Казахстан Жакен Кожахметович Таймагамбетов.

Этой наградой от имени Императора Японии награждают иностранных граждан за выдающиеся заслуги в сфере развития дружественных отношений с Японией. До этого времени шесть граждан Казахстана, включая Первого Президента РК Н. А. Назарбаева были удостоены Ордена Японии.

Таймагамбетов Ж. К. отмечен за вклад в углубление научных от- ношений между Японией и Казахстаном и содействие взаимопонимания между странами, посредством проведения совместных археологических раскопок, конференций, чтения лекций, издания научных трудов в обеих странах.

Международное признание к ученому пришло благодаря научным достижениям, берущим истоки еще со студенческих времен, научной стажировке и за годы учебы в аспирантуре у основателя сибирской археологической школы академика АН СССР А. П. Окладникова в г. Новосибирске, где он знакомится со многими археологами СССР, корифеями в области палеолитоведения - профессорами П. И. Борисковским, В. П. Любиным, 3. А. Абрамовой, А. П. Деревянко и др. Новосибирский период, в частности отражен в интервью его научного руководителя А. П. Окладникова: «... У меня много учеников. Самый юный - казах Жакен Таймагамбетов. 
Мамиров Т.Б. Казахстанский археолог удостоен японской награды «Орден восходящего солнца с золотыми лучами, с лентой на шее»

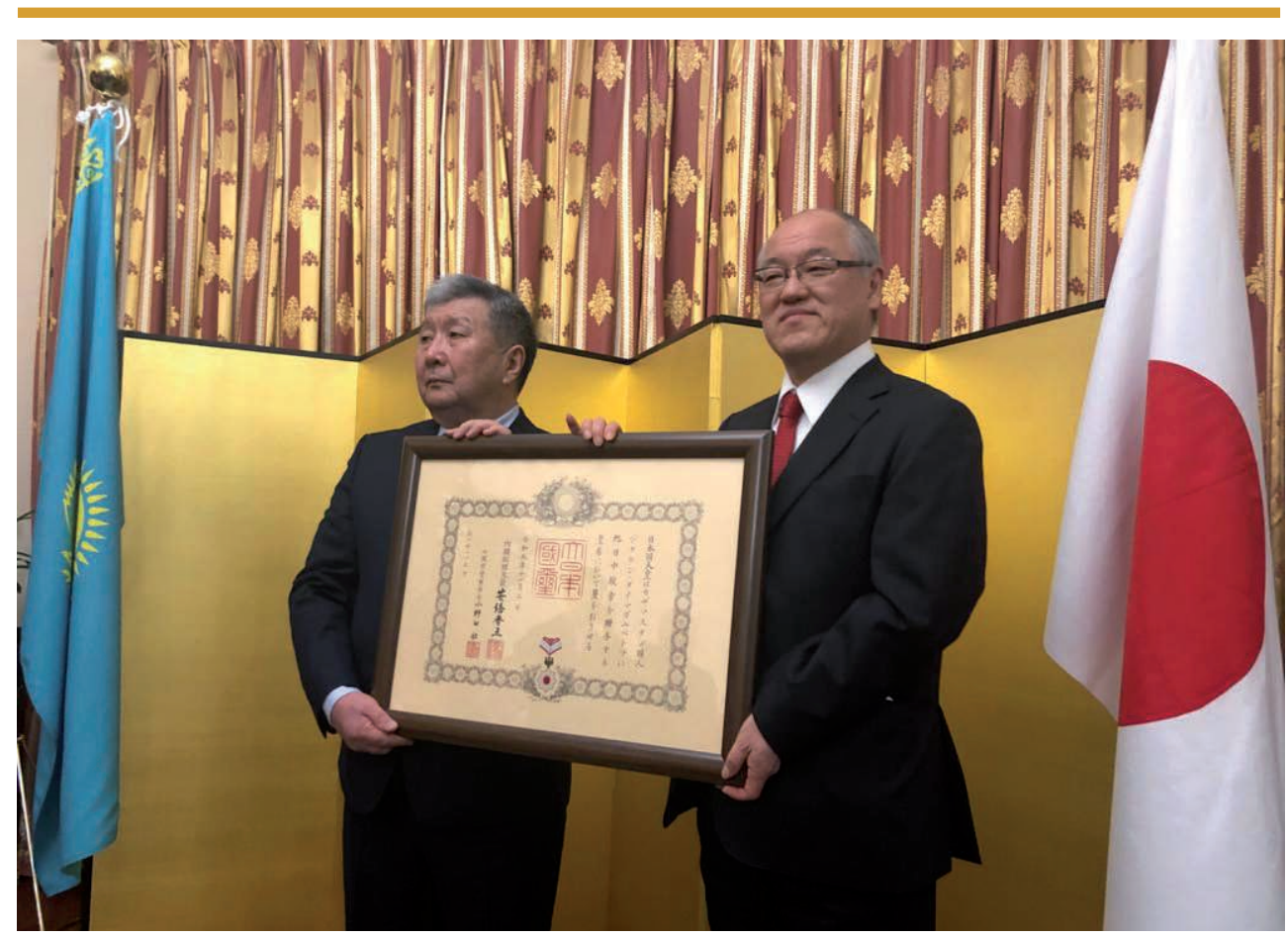

Рис. 1. Вручение награды Ж.К. Таймагамбетову Чрезвычайным и Полномочным Послом Японии в Республике Казахстан господином Таиухико Касаи

Fig. 1. Presentation of the award Zh.K. Taimagambetov, Ambassador Extraordinary and Plenipotentiary of Japan to the Republic of Kazakhstan, Mr. Tatsuhiko Kasai

Он с такой энергией, самоотверженно работал на Алтае, участвовал в раскопках, нашел интересные памятники древней культуры. Приятно знать, что есть такие ученики, как Жакен ...» [цит. по: Соловьева, 1983, с. 208]. Несомненно, такое солидное научное окружение и среда оказали значительное влияние на научное мировоззрение и формирование Ж. К. Таймагамбетова как профессионального археолога, безмерно преданного своему делу, вот уже на протяжении 40 лет.

Его научные интересы: антропогенез; история древнейших культур Евразии; проблемы заселения территории Центральной Азии и Казахстана первобытным человеком, его культура, миграции и этнические связи.

С 1980 года и по сей день Ж. К. Таймагамбетов постоянный ру- ководитель целого ряда археологических экспедиций по изучению памятников каменного века на территории Казахстана. Совместно с академиком А. П. Деревянко открыл и исследовал десятки археологических объектов в разных регионах Казахстана, в том числе ставшие эталонными и получившие мировую известность - Кошкурган, Шоктас, Кызылтау, Мугоджары, Майбулак, Ушбулак и др.

Он является инициатором и со-руководителем международных программ по комплексному изучению открытых и пещерных памятников палеолита Казахстана таких как Казахстано-Германская экспедиция (с 2015 г. пон.в.); Казахстано-Российская экспедиция (1992-2002 гг., с 2015 г. по н.в.); Казахстано-Японская экспедиция (с 2017 г. по н.в.) с участи- 
ем специалистов из США, Германии, Италии, Румынии, Бельгии, Японии, Бразилии, и др. стран.

В статье хотелось бы обратить внимание на контактах Ж. К. Таймагамбетова с японскими археологами. В начале 80-х годов прошлого столетия Жакен Кожахметович, будучи аспирантом, знакомится с археологами из университета Хоккайдо, Саппоро - Хидеаки Кимурой и Харуо Ойи. Тесное же научное сотрудничество с японскими археологами началось в 2008 г., когда Ж. К. Таймагамбетов работал деканом факультета истории, археологии и этнологии КазНУ им. аль-Фараби, которое продолжилось в 2010 году посещением КазНУ им. аль-Фараби археологов из Национального исследовательского Института культурных ценностей Нара, Японского центра Международного сотрудничества и сохранения культурного наследия Токио для налаживания научных контактов. Археологи с главой региональной секции окружающей среды из Токио г-ном Казуя Ямаучи прослушали курс лекций профессора Ж.К. Таймагамбетова об антропогенезе и палеолите Казахстана, знакомились с новейшими достижениями и результатами экспедиции по изучению памятников каменного века Казахстана, посетили места раскопок палеолитических стоянок, обработали коллекции каменных орудий из фонда Музея палеолита.

В 2012 г., по приглашению руководства Национального исследовательского Института культурных ценностей Нара состоялся ответный визит Ж. К. Таймагамбетова в университет Хоккайдо, институт Нара с лекцией для студентов и Ассоциации археологов Японии.
C 2017 г. начинаются работы совместной Казахстано-Японской археологической экспедиции под руководством профессора Ж. К. Таймагамбетова и профессора С. Кунитаке из Научно-исследовательского института культурных ценностей Нара. За три полевых сезона были открыты новые памятники каменного века на территории Южного Казахстана. Одним из направлений работ стало уточнение стратиграфического разреза на стоянке им. Ч. Валиханова в Южном Казахстане. Если ранее было известно о шести культурных слоях, залегающих in situ, то в результате работ последних двух лет, впервые на стоянке в нижних отложениях выявлены еще три культурных слоя, и общее число их достигло девяти, что свидетельствует об обитании древнего человека на протяжении длительного времени в одном и том же месте [Таймагамбетов, Кунитаке, 2019].

В Жамбылской области, в районе с. Тамды была впервые обнаружена стратифицированная стоянка верхнепалеолитического времени, Буйрек-бастаубулак. В результате двухлетних раскопок, выявлены каменные орудия, среди которых пластины и отщепы с ретушью, проколки и резцы, а также большое количество нуклеусов, предназначенных для снятия пластин и отщепов. В 2019 г. обнаружены остатки кострищ и очагов. Для определения абсолютного возраста памятника взяты образцы угля и почвы и отправлены в лабораторию Японии.

Помимо археологических экспедиций научное сотрудничество между нашими странами ведется и в области консервации и реставрации археологических артефактов, стажировках, совместных конференциях, 
Мамиров Т.Б. Казахстанский археолог удостоен японской награды «Орден восходящего солнца с золотыми лучами, с лентой на шее»

чтениях лекций. Одним из результатов такого сотрудничества стала презентация коллективной монографии «Изучение верхнепалеолитической культуры в Казахстане» на японском языке в стенах Национального музея РК. В публикации книги приняли участие профессор Ж. К. Таймагамбетов, археологи из Японии С. Кунитаке, С. Моримото, С. Като, К. Шиба и др.

По его инициативе и руководством в КазНУ им. аль-Фараби создан единственный в СНГ Музей палеолита Казахстана, а затем открыта международная научно-исследовательская лаборатория «Геоархеология», призванная на основе естественнонаучных дисциплин изучать и датировать археологические памятники и артефакты на территории Казахстана и Центральной Азии. В должности замдиректора в Национальном музее РК в Астане им инициировано открытие при музее научно-исследовательского Института «Халық қазынасы».

Профессор Ж. К. Таймагамбетов известен активной педагогиче- ской работой в археологии. Под его руководством защищены две докторские диссертации $\mathrm{PhD}$, подготовлено девять кандидатов наук, десятки магистров по истории, археологии. Он является руководителем докторских диссертаций соискателей из Кыргызстана. В настоящее время ученики Ж. К. Таймагамбетова работают в Кыргызстане, России, Франции, Японии. Жакен Кожахметович - автор и соавтор более 470 научных работ, из них 50 монографий, учебников, многие из них изданы на 12 языках мира.

Многолетняя научная и педагогическая деятельность Ж. К. Таймагамбетова отмечена многими правительственными и ведомственными наградами РК, в том числе и зарубежными: юбилейной медалью Республики Туркменистан «11 лет Независимости Туркменистана». Сегодня, к этим наградам добавился заслуженный «Орден Восходящего солнца с золотыми лучами, с лентой на шее» Японии.

\section{ЛИТЕРАТУРА}

1. Соловьева Г.С. Загадка счастья: опыт философского размышления. Алма-Ата: Жалын, 1983. 229 с.

2. Таймагамбетов Ж., Кунитаке C. 60 лет со дня открытия многослойной палеолитической стоянки им. Ч. Валиханова // Қазақстан археологиясы. 2019. № 3 (5). C. 62-71.

\section{Сведения об авторе:}

Мамиров Талгат Базарбаевич, кандидат исторических наук, директор, Филиал Института археологии им. А.Х. Маргулана в г. Нур-Султан (г. Нур-Султан, Казахстан); tmamirov@mail.ru

\section{ҚАЗАҚСТАНДЫҚ АРХЕОЛОГ «АЛТЫН ШУАҚ МОЙЫН ЛЕНТАСЫ, КҮНШЫҒЫС ОРДЕНІ» ЖАПОН МАРАПАТЫНА ИЕ БОЛДЫ}

\section{Т. Б. Мамиров}

Мақалада белгілі археолог Жәкен Қожахметұлы Таймағамбетовтің ғылыми қызметінің кейбір нәтижелері берілген. Негізгі назар Ж.К. Таймағамбетовтің ғалым ретінде қалыптасуына, жапон археологтарымен ынтымақтастықығы және зерттеушінің 
Қазақстан палеолитін зерттеудегі ғылыми үлесіне аударылады. Ғалымның ғылыми қызығушылығы: антропогенез, Еуразияның ежелгі мәдениеттерінің тарихы, Орта Азия мен Қазақстанның территориясындағы ежелгі адамдардың қоныстану мәселелері.

Түйін сөздер: археология, Ж.Қ. Таймағамбетов, ғылым, ғалым, тас дәуірі, палеолит

\section{KAZAKHSTAN ARCHAEOLOGIST AWARDED THE JAPANESE AWARD «MEDAL OF THE RISING SUN WITH GOLD RAYS, WITH A TAPE ON THE NECK»}

\section{T. B. Mamirov}

The article provides some results of the scientific activity of the famous archaeologist $\mathrm{Zh}$. K. Taimagambetov. The main attention is paid to the formation of Zh.K. Taimagambetov as a scientist-archaeologist, collaborating with Japanese archaeologists, and the scientific contribution of the researcher to the study of the Paleolithic of Kazakhstan. The scientific interests of the scientist: anthropogenesis, the history of the most ancient cultures of Eurasia, the problems of the settlement of the territory of Central Asia and Kazakhstan by primitive man.

Keywords: archaeology, Zh.K. Taimagambetov, science, scientist, Stone Age, Paleolithic.

\section{REFERENCES}

1. Soloviyova, G. S. 1983. Zagadka schastiya: opyt filosofskogo razmyshleniya (The riddle of happiness: the experience of philosophical reflection). Alma-Ata: "Jalyn" Publ. (in Russian).

2. Taymagambetov, J., Kunitake, S. 2019. In Kazakhstan Archeology, 3 (5), 62-71.

\section{About the Author:}

Mamirov Talgat B. Candidate of Historical Sciences, Director, Branch of the A.Kh. Margulan Archeology Institute in Nur-Sultan, Nur-Sultan, Kazakhstan; tmamirov@mail.ru

Мақала туралы ақпарат / Информация о статье / Information about the article.

Жариялауға қабылданды / Принята к публикации / Accepted for publication: 08.01.2020. 